\title{
Faktor - Faktor yang Berhubungan dengan Ibu Hamil dalam Memanfaatkan Layanan Voluntary Counseling and Testing
}

\author{
Sri Melda Br Bangun, Basyariah Lubis², Raisha Octavariny², Surio \\ Retno $^{4}$
}

\author{
1,2,3,4 Institut Kesehatan Medistra Lubuk Pakam \\ JIn. Sudirman No. 38 Lubuk Pakam Kab. Deli Serdang \\ e-mail : meldabangun24@gmail.com
}

DOI : https://doi.org/10.35451/jkk.v2i1.253

\begin{abstract}
HIV (Human Immunodeficiency Virus) and AIDS (Acquired Immune Deficiency Syndrome $\neg$ e) became a matter of global emergency. Worldwide, 35 million people live with HIV and 19 million do not know their positive HIV status (UNAIDS, 2014). Indonesia has become one of the countries in the world with the fifth highest risk in the spread of HIV / AIDS (Ministry of Health, 2013). The highest percentage of HIV infections was reported in the age group of 25 49 years $(69.2 \%)$, followed by the age group $20-24$ years $(16.7 \%)$ and the age group $\geq 50$ years $(7.6 \%)$. While the highest AIDS percentage was in the 30-39 years age group (35.2\%), followed by the 20-29 years age group $(29.5 \%)$ and the $40-49$ years age group (17.7\%). Currently in Indonesia there is an increase in HIV / AIDS prevalence among housewives, followed by a high HIV prevalence in children. Many women are classified as vulnerable to contracting STIs and HIV because their spouses have unprotected sexual behavior outside of marriage and use injecting drugs. One of the methods used by the government to prevent the spread of HIV among the public is through VCT (Voluntary Counseling and Testing) services available at the Puskesmas. This service is a voluntary and confidential counseling activity, which is carried out before and after blood tests to check the status of the Human Immunodeficiency Virus (HIV) at the Puskemsas laboratory. This study used a cross sectional study design with a sample of 50 pregnant women using the stratified random sampling method with the chi-square test. The results showed that there was a relationship between age, employment status, knowledge, attitude, and distance of pregnant women in utilizing voluntary counseling and testing services.
\end{abstract}

Keywords: Age, occupation, knowledge, attitude, and distance

\section{Pendahuluan}

Kementrian Kesehatan RI (2017) memperkirakan jika di Indonesia setiap tahunnya terdapat 9.000 ibu hamil positif Human Immunodeficiency Virus (HIV) yang melahirkan bayi, berarti akan lahir sekitar 8.604 bayi dengan HIV positif tiap tahun. Menurut Sitohang (2018), terdapat 36, 9 juta orang hidup dengan HIV dimana 1,8 juta diantaranya adalah anak-anak di bawah 15 tahun. Ibu atau bayi dengan HIV atau Acruired Immunodefiency Syndrome (AIDS) berpeluang besar untuk menyumbang angka kematian ibu maupun bayi yang 
sangat menentukan derajat kesehatan masyarakat di suatu Negara.

Kasus HIV/AIDS di propinsi Sumatera Utara menempati posisi peringkat ke 7 di Indonesia, laporan mengenai masyarakat yang terkena HIV/AIDS hingga Juli 2018 sebesar 8.877 orang. Dari data tersebut yang terpapar 3.840 orang terinfeksi HIV dan 5.037 sudah terkena AIDS (Widyastuti, 2018).

Sementara itu, di Kabupaten Simalungun, sebanyak 5.333 orang beresiko yang berkunjung ke klinik voluntary counseling and test (VCT). Akan tetapi, hal ini tidak sebanding dengan estimasi populasi berisiko HIV/AIDS ditahun 2017 di Kabupaten Simalungun yaitu, 20.000 orang (P2P Dinkes Simalungun, 2018). Kabupaten Simalungun, terdapat 6 instansi layanan VCT. Berdasarkan laporan tahun 2017 di Kabupaten Simalungun dari 5,333 orang yang memanfaatkan layanan VCT, dinyatakan 55 orang yang terdeteksi HIV positif yang berasal dari populasi beresiko.

Berdasarkan uraian diatas maka dilakukan penelitian yang bertujuan untuk mengetahui faktor-faktor yang berhubungan dengan ibu hamil dalam memanfaatkan layanan VCT.

\section{METODE PENELITIAN}

Penelitian ini bersifat analitik dengan menggunakan pendekatan cross sectional yang bertujuan untuk mengetahui faktor-faktor yang berhubungan dengan ibu hamil dalam memanfaatkan layanan VCT di wilayah kerja puskesmas Tapian Dolok. Populasi dalam penelitian ini adalah seluruh ibu hamil yang berjumlah 800 orang.

Wilayah kerja Puskesmas Tapian Dolok memiliki 11 kelurahan (nagori) masing-masing diambil sampel dengan menggunakan metode stratified Random Sampling dengan kuesioner.
Analisa data dilakukan dengan analisa univariat dan bivariate menggunakan uji chi-square dengan tingkat kepercayaan $95 \%$

\section{HASIL}

Berdasarkan tabel 1 diketahui jumlah sampel dalam penelitian ini adalah sebanyak 50 orang yang diambil dari 11 wilayah kerja yang ada di Puskesmas Tapian Dolok

Tabel 1. Sampel ibu hamil berdasarkan desa binaan di wilayah kerja Puskesma Tapian Dolok

\begin{tabular}{|c|c|c|}
\hline \multicolumn{2}{|c|}{$\begin{array}{c}\text { No Kelurahan } \\
\text { /Nagori }\end{array}$} & \multirow{2}{*}{$\begin{array}{l}\text { Sampel } \\
160 / 800 \times 50=10\end{array}$} \\
\hline 1 & Sinaksak & \\
\hline 2 & Nagur Usang & $50 / 800 \times 50=3$ \\
\hline 3 & Purbasari & $85 / 800 \times 50=6$ \\
\hline 4 & Dolok Maraja & $80 / 800 \times 50=5$ \\
\hline 5 & Dolok Ulu & $60 / 800 \times 50=4$ \\
\hline 6 & Dolok Kahean & $70 / 800 \times 50=4$ \\
\hline 7 & $\begin{array}{l}\text { Pematang } \\
\text { Kahean }\end{array}$ & $60 / 800 \times 50=4$ \\
\hline 8 & $\begin{array}{l}\text { Nagori Bayu } \\
\text { Muslimin }\end{array}$ & $50 / 800 \times 50=3$ \\
\hline 9 & Dolok Simbolon & $55 / 800 \times 50=3$ \\
\hline 10 & Batu Silangit & $55 / 800 \times 50=3$ \\
\hline 11 & Naga Dolok & $75 / 800 \times 50=5$ \\
\hline & Total & 50 ibu hamil \\
\hline
\end{tabular}

Berdasarkan tabel 2 diketahui umur ibu hamil mayoritas berada pada usia dewasa > 24 tahun sebanyak 28 orang (56\%) dan 22 orang dewasa muda $\leq 24$ tahun, yang tidak bekerja 26 orang $(52 \%)$ dan bekerja 24 orang (48), yang memiliki pengetahuan kurang 32 orang $(64 \%)$ dan baik 18 orang $(36 \%)$, dan jarak tempuh jauh dan dekat sebanyak 25 orang (25\%)

Tabel 2. Distribusi frekuensi berdasarkan umur, pekerjaan, pengetahuan, sikap, jarak tempuh dan keberadaan layanan VCT di Puskesmas Tapian Dolok

Umur (tahun) $\quad$ f $\quad \%$




\begin{tabular}{lll}
\hline$\leq 24$ & 22 & 44 \\
$>24$ & 28 & 56 \\
\hline Pekerjaan & f & \% \\
\hline Tidak bekerja & 26 & 52 \\
Bekerja & 24 & 48 \\
\hline Pengetahuan & f & \% \\
\hline Kurang & 32 & 64 \\
Baik & 18 & 36 \\
\hline Sikap & $\mathbf{f}$ & $\mathbf{\%}$ \\
\hline Kurang & 28 & 56 \\
Baik & 22 & 44 \\
\hline Jarak tempuh & $\mathbf{f}$ & $\mathbf{\%}$ \\
\hline Jauh & 25 & 50 \\
Dekat & 25 & 50 \\
\hline
\end{tabular}

Berdasarkan tabel 3. umur ibu hamil < 24 tahun dalam memanfaatkan VCT sebanyak 9 orang (18\%) dan tidak sebanyak 13 orang (26\%). Sedangkan usia $\geq 24$ tahun yang memanfaatkan VCT sebanyak 20 orang $(40 \%)$ dan yang tidak sebanyak 8 orang $(16 \%)$, dengan pValue $(=0.03)<a(=0,05)$, dimana Ha diterima, ada hubungan umur ibu hamil dalam memanfaatkan VCT.

Tabel 3. Hubungan umur ibu hamil dalam memanfaatkan layanan VCT

\begin{tabular}{|c|c|c|c|c|c|c|c|}
\hline \multirow{3}{*}{$\begin{array}{c}\text { Umur } \\
\text { (tahun) }\end{array}$} & \multicolumn{4}{|c|}{ Pemanfaatan VCT } & \multirow{2}{*}{\multicolumn{2}{|c|}{ Total }} & \multirow{3}{*}{$P$} \\
\hline & \multicolumn{2}{|l|}{$\mathrm{Ya}$} & \multicolumn{2}{|c|}{ Tidak } & & & \\
\hline & $f$ & $\%$ & $f$ & $\%$ & $f$ & $\%$ & \\
\hline$\leq 24$ & 9 & 18 & 13 & 26 & 22 & 44 & \multirow{3}{*}{0.03} \\
\hline$>24$ & 20 & 40 & 8 & 16 & 28 & 56 & \\
\hline Total & 29 & 58 & 21 & 42 & 50 & 100 & \\
\hline
\end{tabular}

Usia mempengaruhi daya tangkap dan pola pikir seseorang. Pada usia menuju dewasa, seseorang akan lebih berperan aktif dalam masyarakat dan kehidupan sosial (Notoatmodjo, 2007). Hal ini sejalan dengan Kemenkes (2014) bahwa orang yang terinfeksi HIV dan AIDS direntang usia produktif. $\mathrm{Hal}$ ini mengindikasikan bahwa ibu hamil lebih didominasi oleh kelompok usia produktif, yaitu rentang $25-45$ tahun (Widoyono, 2008). Dalam kaitannya dengan usia reproduktif, seseorang yang memiliki usia reproduktif sangat perlu memperhatikan sistem, fungsi dan proses produksi yang mereka miliki, karena orang dengan usia reproduktif sangat membutuhkan layanan kesehatan. Salah satu layanan kesehatan yang seharusnya didapat ibu hamil yaitu kesehatan reproduksi.

Berdasarkan tabel 4. status ibu hamil yang tidak bekerja yang memanfaatkan VCT sebanyak 11 orang (22\%) dan tidak sebanyak 15 orang (30\%). Sedangkan status bekerja yang memanfaatkan layanan VCT sebanyak 18 orang $(36 \%)$ dan yang tidak sebanyak 6 orang $(12 \%)$, dengan pValue $(=0.03)<a(=0,019)$, dimana $\mathrm{Ha}$ diterima, ada hubungan status pekerjaan ibu hamil dalam memanfaatkan VCT.

Tabel 4. Hubungan status pekerjaan ibu hami dalam memanfaatkan layanan VCT

\begin{tabular}{|c|c|c|c|c|c|c|c|}
\hline \multirow{3}{*}{$\begin{array}{l}\text { Status } \\
\text { bekerja }\end{array}$} & \multicolumn{4}{|c|}{ Pemanfaatan VCT } & \multicolumn{2}{|c|}{ Total } & \multirow{3}{*}{$p$} \\
\hline & \multicolumn{2}{|l|}{ Ya } & \multicolumn{2}{|c|}{ Tidak } & \multirow[b]{2}{*}{$f$} & \multirow[b]{2}{*}{$\%$} & \\
\hline & $f$ & $\%$ & $f$ & $\%$ & & & \\
\hline Tidak & 11 & 22 & 15 & 30 & 26 & 52 & \\
\hline Bekerja & 18 & 36 & 6 & 12 & 24 & 48 & 0.03 \\
\hline Total & 29 & 58 & 21 & 42 & 50 & 100 & \\
\hline
\end{tabular}

Bekerja adalah salah satu upaya untuk mendapatkan pamasukan, sehingga dapat memenuhi kebutuhan dan meningkatkan kesejahteraan. Tingkat kesejahteraan yang baik dapat meningkatkan akses seseorang ke layanan kesehatan untuk menjaga status kesehatannya agar tetap baik (Indriyani, 2012).

Dari penelitian yang dilakukan oleh Purwaningsih (2011), menyatakan bahwa individu yang memiliki riwayat pekerjaan yang jelas berisiko terinfeksi HIV/AIDS mungkin akan lebih mudah 
memotivasi

dirinya untuk

memanfaatkan VCT karena ia menyadari bahaya yang akan dialami sedangkan individu yang beranggapan bahwa dirinya tidak berisiko, kemungkinan tidak akan melakukan VCT. Hal ini secara tidak langsung dapat memperluas penularan HIV/AIDS karena individu yang menganggap bahwa dirinya tidak memiliki pekerjaan yang berisiko cenderung untuk tidak melakukan VCT. Adanya anggapan tersebut dapat menyebabkan individu tidak menyadari bahwa dirinya telah tertular HIV/AIDS.

Berdasarkan tabel 5, pengetahuan ibu hamil yang kurang dalam memanfaatkan VCT sebanyak 14 orang (28\%) dan tidak sebanyak 18 orang (30\%). Sedangkan berpengetahuan baik yang memanfaatkan layanan VCT sebanyak 15 orang $(30 \%)$ dan tidak sebanyak 3 orang $(12 \%)$, dengan pValue $(=0.006)<a(=0,05)$, dimana $\mathrm{Ha}$ diterima yaitu ada hubungan pengetahuan ibu hamil dalam memanfaatkan VCT.

Tabel 5. Hubungan pengetahuan ibu hamil dalam memanfaatkan layanan VCT

\begin{tabular}{|c|c|c|c|c|c|c|c|}
\hline \multirow{3}{*}{$\begin{array}{l}\text { Pengeta } \\
\text { huan }\end{array}$} & \multicolumn{4}{|c|}{ Pemanfaatan VCT } & \multirow{2}{*}{\multicolumn{2}{|c|}{ Total }} & \\
\hline & \multicolumn{2}{|l|}{ ya } & \multicolumn{2}{|c|}{ Tidak } & & & \\
\hline & $f$ & $\%$ & $f$ & $\%$ & $f$ & $\%$ & \\
\hline Kurang & 14 & 28 & 18 & 30 & 32 & 64 & 0. \\
\hline Baik & 15 & 30 & 3 & 12 & 18 & 36 & 0 \\
\hline Total & 29 & 58 & 21 & 42 & 50 & 100 & 6 \\
\hline
\end{tabular}

Sumarlin (2013), menyatakan ada pengaruh pengetahuan terhadap perubahan perilaku pada pasien HIV/AIDS. Pengetahuan baik lebih besar kemungkinan untuk melakukan perubahan perilaku dengan persentase $(65,7 \%)$. Didukung pula dengan penjelasan menurut Notoatmodjo (2009) bahwa pengetahuan merupakan strategi perubahan perilaku yang penting untuk menimbulkan kesadaran dan akhirnya berperilaku sesuai dengan pengetahuan yang dimilikinya. Berdasarkan teori adaptasi, apabila seseorang memiliki tingkat pengetahuan yang baik setidaknya dapat mendorong untuk mempunyai sikap dan perilaku yang baik pula. Seseorang akan berperilaku didasarkan beberapa pertimbangan yang diperoleh dari tingkat pengetahuannya. Hal ini juga sejalan dengan penelitian yang dilakukan oleh Cicio (2010) hasil penelitian menunjukkan bahwa sebagian besar informan yang ditelitinya tidak memanfaatkan layanan VCT dikarenakan mereka tidak tahu apa itu VCT dan untuk apa layanan VCT. Sehingga disimpulkan ketertarikan seseorang terhadap layanan VCT dilatarbelakangi oleh pengetahuan seseorang tentang layanan VCT.

Berdasarkan tabel 6, sikap ibu hamil yang kurang dalam memanfaatkan layanan VCT sebanyak 12 orang $(24 \%)$ dan tidak sebanyak 16 orang (32\%). Sedangkan bersikap baik yang memanfaatkan layanan VCT sebanyak 17 orang (30\%) dan yang tidak sebanyak 5 orang (12\%), dengan pValue $(=0.014)<a(=0,05)$, dimana Ha diterima yaitu ada hubungan sikap ibu hamil dengan pemanfaatan layanan VCT

Tabel 6. Hubungan sikap ibu hamil dalam memanfaatkan layanan

VCT

\begin{tabular}{|c|c|c|c|c|c|c|c|}
\hline \multirow{3}{*}{ Sikap } & \multicolumn{4}{|c|}{$\begin{array}{l}\text { Pemanfaatan } \\
\text { layanan VCT }\end{array}$} & \multirow{2}{*}{\multicolumn{2}{|c|}{ Total }} & \multirow{3}{*}{$P$} \\
\hline & \multicolumn{2}{|l|}{$\mathrm{Ya}$} & \multicolumn{2}{|c|}{ Tidak } & & & \\
\hline & $f$ & $\%$ & $f$ & $\%$ & $f$ & $\%$ & \\
\hline Kurang & 12 & 24 & 16 & 32 & 28 & 56 & \\
\hline Baik & 17 & 30 & 5 & 12 & 22 & 44 & 0.014 \\
\hline Total & 29 & 58 & 21 & 42 & 50 & 100 & \\
\hline
\end{tabular}

Sikap merupakan kesiapan untuk bereaksi terhadap objek di lingkungan tertentu sebagai suatu penghayatan 
terhadap objek (Notoatmodjo, 2007). Sikap dapat menggambarkan suka atau tidak suka seseorang terhadap objek. Biasanya sikap diperoleh dari pengalaman sendiri atau orang lain yang paling dekat.

Berdasarkan tabel 7, jarak tempuh ibu hamil yang jauh dalam memanfaatkan VCT sebanyak 10 orang (20\%) dan tidak sebanyak 15 orang $(30 \%)$. Sedangkan yang dekat dalam memanfaatkan VCT sebanyak 19 orang (38\%) dan yang tidak sebanyak 6 orang $(12 \%)$, dengan pValue $(=0.010)$ $<$ a $(=0,05)$, dimana Ha diterima ada hubungan jarak tempuh dalam memanfaatkan layanan VCT.

Tabel 7. Hubungan jarak tempuh ibu hamil dalam memanfaatkan layanan VCT.

\begin{tabular}{|c|c|c|c|c|c|c|c|}
\hline \multirow{4}{*}{$\begin{array}{l}\text { Jarak } \\
\text { tempuh }\end{array}$} & \multicolumn{4}{|c|}{ Pemanfaatan } & \multirow{2}{*}{\multicolumn{2}{|c|}{ Total }} & \multirow{4}{*}{$P$} \\
\hline & & & anar & ICT & & & \\
\hline & \multicolumn{2}{|l|}{$\mathrm{Ya}$} & \multicolumn{2}{|c|}{ Tidak } & & & \\
\hline & $f$ & $\%$ & $f$ & $\%$ & $f$ & $\%$ & \\
\hline Kurang & 10 & 20 & 15 & 30 & 25 & 50 & \multirow{3}{*}{0.01} \\
\hline Dekat & 19 & 38 & 6 & 12 & 25 & 50 & \\
\hline Total & 29 & 58 & 21 & 42 & 50 & 10 & \\
\hline
\end{tabular}

Hal ini sesuai dengan penelitian Kassyou (2011) dan Tighe (2012), yang menyatakan transportasi yang sulit atau waktu tempuh yang lama akan mengakibatkan munculnya perasaan malas atau enggan untuk pergi ke tempat pelayanan kesehatan dan untuk memanfaatkan layanan VCT, hal ini juga diperkuat oleh Oktavinola (2010) yang mengatakan bahwa jarak ke fasilitas kesehatan yang jauh dan tidak strategis akan sulit dicapai oleh para ibu hamil sehingga menyebabkan kurangnya akses ibu hamil terhadap pemeriksaan VCT

\section{KESIMPULAN}

Berdasarkan hasil penelitian bahwa distribusi frekuensi untuk umur ibu hamil berada pada usia dewasa $>24$ tahun sebanyak $56 \%$, Status pekerjaan mayoritas tidak bekerja sebanyak $52 \%$, pengetahuan berada pada kategori kurang sebesar 64\%, sikap ibu hamil pada kategori kurang sebesar 62\%, dan informasi tentang keberadaan layanan VCT tidak mengerti sebesar $34 \%$. Seluruh variabel dalam penelitian ini memiliki hubungan dalam memanfaatkan layanan VCT dimana $p$ value $<0.05$

\section{DAFTAR PUSTAKA}

Dinkes Simalungun. 2018. Laporan Bidang Pengendalian dan Pemberantasan Penyakit. Dinas Kesehatan Kabupaten Simalungun. Sumatera Utara.

Kemenkes RI. 2015 Pedoman Pelaksanaan Pencegahan Penularan HIV dan Siflis Dari Ibu ke Anak Bagi Tenaga Kesehatan. Direktoral Jenderal Bina Kesehatan Ibu dan Anak : Jakarta.

Kementrian Kesehatan RI, 2018. Hari AIDS Sedunia, Momen STOP Penularan HIV: Saya Berani, Saya Sehat. Diunduh 12 Januari 2019. Http://www.depkes.go.id

Kemenkes, RI. 2017 Pedoman Eliminasi Penularan HIV,Siflis Dan Hepatitis B Dari Ibu Ke Anak. Direktoral Jenderal Pencegahan Dan Pengendalian Penyakit: Jakarta.

Kemenkes, RI. 2016 Petunjuk Teknis Program Pengendalian HIV AIDS Dan PIMS Fasilitas Kesehatan Tingakat Pertama. Direktoral Jenderal Pencegahan dan Pengendalian Penyakit: Jakarta.

Kemenkes, RI. 2014. Laporan Perkembangan HIV-AIDS di Indonesia Triwulan III tahun 2014. Ditjen PP \& PL Kemenkes RI. Jakarta. 
(1)=="

Received: 18 September 2019 :: Accepted: 30 September 2019:: Publish: 31 Oktober 2019

Notoatmodjo, S. 2007. Promosi

Kesehatan \& Ilmu Perilaku

Kesehatan. Jakarta. Rineka

Cipta.

SIHA, Puskesmas Tapian Dolok. 2017.

Sistem Informasi HIV-AIDS.

Puskesmas Tapian Dolok.

Kabupaten Simalungun. 